\title{
Measure the Unmeasurable? Intangible Assets as the Major Strategic Keys of Enterprises, Their Contribution, Difficulties and Proposals for Reliable Financial Statements
}

\author{
Gkinoglou Emmanouil \\ Tax and Business Consultant, Thessaloniki, Greece \\ Ginoglou Dimitrios \\ University of Macedonia, Thessaloniki, Greece
}

\begin{abstract}
It is a common belief, for the last two decades, that we can observe the transformation of the international economy, from industrial to knowledge economy. In a continuous changing economy, the main advantage the companies have is not the buildings, the machines, the trucks, or the total equipment. The strategic key of a company today is the capital that cannot be copied easily, that is not disclosed and is not tangible, the intellectual capital of the company. The intangible assets can be characterized as those without physical appearance and the value of which is limited by the rights and anticipative benefits that possession confers upon the owner. The expansion of companies into foreign markets presupposes the aggregation of financial information that includes non-homogeneous elements. The purpose of this paper is to examine the framework of identification, as well as the disclosure requirements of brand names as they have been set by several articles of Commercial Law and recognized by professional accounting institutions. Emphasis will be given to analyzing existing accounting recognition and measurement, and proposals worldwide. In conclusion, this study indicates the accounting problems of definition, measurement, and disclosure of the majority of these intangible assets to users of financial statements of the company. Despite all the difficulties, this property of the company must in some way be measured and disclosed to lead to more reliable financial statements. The proposals of this paper, will help the accounting community to solve this major problem.
\end{abstract}

Keywords: accounting, intangible assets, measurement of intangible assets, intellectual capital, brand name, intellectual capital, R\&D, IFRS

\section{Introduction}

The major and most common problem that faces companies today, is the reason why two equivalent products, manufactured out of the same materials, by the same machines, in similar factories and also distributed in the same way and in the same places are seen in different ways from the consumer's/client's point of view. The answer is hidden somewhere in the field of intangible assets. The strategic key for an enterprise to add value to products is more than ever now, its intellectual property.

Gkinoglou Emmanouil, self employed, Tax and Business Consultant, Thessaloniki, Greece.

Ginoglou Dimitrios, professor, Department of Accounting and Finance, University of Macedonia, Thessaloniki, Greece.

Correspondence concerning this paper should be addressed to Gkinoglou Emmanouil, Danaidon 9, 2nd floor, Thessaloniki 54626, Greece. 
The last two decades, from the middle 1990's, the intangible assets is the main problem for academics and professional accountants/consultants. The main problem is the asymmetry of information for the users of financial statements (banks, suppliers, investors, personnel, etc.). This information about the intellectual property of the company does not appear in the Annual Financial Statements. That is the reason why the information loses a major piece, the intellectual capital.

\section{The Immeasurable}

What differentiates two similar, competitive enterprises, that are activated in the same sector, commercial or productive, in the same region, with similar suppliers and similar quality of produced product, is not the factories, not the buildings of administration, not the machines, not the trucks for the distribution, not the products. What differentiates two products from different enterprises, in the brain and the choice of consumer, is the intellectual capital of enterprises, which constitutes property of each enterprise, and is not presented and not valued most times in the balance-sheet of enterprise. However, this capital is the one that offers in each enterprise the competitive advantage, and the possibility that its own product has been preferred by the consumers against the competition.

A characteristic example appears to be the personal computer (PC) in the modern season but also in the direct past. Even if a simple, daily computer is constituted by the same quantity of raw material of which computer was manufactured five years ago (iron, plastic, silicone), these raw materials are used in such a way today that makes the computers 30 times more powerful. The reason is that, the materials are manufactured in such a way so that they attribute to the computer more technological possibilities, usefulness and extension add value. What, therefore, was added in the final product in order to assure it of acquiring higher value and possibilities is the intellectual capital of producer of enterprise.

\section{Categories of Intangible Assets of Strategic Importance for the Enterprises}

With a broader interpretation of the contribution of intellectual capital, that does not appear, is not portrayed or is counted, but it adds value to the enterprise and reinforces the opinion of strategic importance of intangibles in the value of enterprise, we can distinguish categories. The existence of these categories in the economic environment of enterprise contributes to the good operation of the entire company, participating thus in the creation of a satisfied general working environment. With a good environment of work, the enterprise functions better and this output is translated in superior quality, better service of customers from each opinion, restriction of losses or natural damage, or financing better agreements and other elements that render the enterprise competitive.

Under the wide regard therefore, we can distinguish as contribution to the maximisation of the output of enterprise, the good labour relations from the state or other organisms. The professional behaviour of enterprise to the third person creates a climate of confidence in and around the enterprise. A good labour environment could also constitute the base for the consolidation of competitive advantage of enterprise. With the term "good labour environment" the ways of behaviour of management are fixed to the workers, and also the workers between them. We could distinguish in regard to the relations of administration to workers factors as: fair and equal confrontation, remuneration depending on the objective value and their offer, respect in the personality of each involved in the life of the enterprise, in any level, interest of administration for all the workers not as their fortune but as individuals, good building installations, even technologically but also with most excellent conditions of hygiene, guarantee, as far as possible, for the diachronic safety in the workplace, etc. 
All the above contribute in the creation of a good labour environment, which improves the reputation of enterprise while it also contributes to the productivity and the quality of products and services. Thus, although individual factors (equal confrontation, justice, respect, solidarity, safety, hygiene, etc.) cannot constitute distinguishable intangible assets of enterprise, as they do not accomplish the before-mentioned terms of recognition of intangible asset, they contribute in the consolidation of other intellectual and intangible assets such as distinction, contracts with customers, clients list, know-how etc. One more factor constitutes the significance of knowledge, which leads to a competitive advantage. The modern enterprising and economic environment in which the enterprises themselves participate, requires the exploitation of knowledge, not only in individual elements of enterprise (channels of distribution, list of clients, market, marketing etc.) but also in the total of enterprise. This knowledge is found incorporated in the systems that are used but also in the competences and the basic advantages of its executives. Thus the challenges that face the enterprises are the growth of mechanisms capable of the localisation and then the management of this particular knowledge that exists in the enterprise, with the primary target the increase of value of knowledge management.

\section{Different Approaches}

For a relatively new subject, it is reasonable that different approaches and different confrontations are proposed from a lot of academics but also from practitioners of the auditing and accounting profession. Therefore, different interpretations are met in the international bibliography for the confrontation of same subject.

Without doubt, from the terms used in the recognition and interpretation of secret fortune of enterprise are:

(1) Intangible Assets;

(2) Intellectual Property;

(3) Intellectual Assets;

(4) Intellectual Capital;

(5) Knowledge Based Assets;

(6) Knowledge Capital.

\section{Efforts for Definition}

\section{International Efforts for Definition-Literature Review}

As in every field of research, the effort to be given concrete and final definition of dimension of intangible assets is particularly difficult. As a result of this complexity, the point of view from which each expert approaches the subject, but mainly the objective that has each researcher through his inquiring work as well as the results in which he aims to identify intangible assets as a multidimensional subject. In the international literature, a lot of proposals were made, different approaches were followed and also tons of ink were poured in congresses, laboratories, scientific articles, and scientific books.

Efforts, both individual and combined from institutions, companies (SKANDIA-ALTEC), Universities (in national and international level of collaborations from institutions (MERITUM)), become more intense after, and henceforth become perceptible that something exists that we cannot distinguish.

After a lot of efforts and a lot of proposals for categorisation and recognition of this type of property, which adds value in an enterprise, the next step was made in the direction of assessment. The objective of all efforts, national or international, collaborations of, professionals or academic proposals, were based on the 
same common way of thought that it is a reliable system of recording and depicting of intangible assets, that leads to assessment of inconspicuous fortune of enterprise with the final aim their depiction to the financing situations of enterprise for relevance and reliability in the Financial Statements of the company.

The effort for the most appropriate definition for the intangibles, stops to the problem of categorization or the separation into the similar groups. The first proposal was Edvinsson and Malone's (1997), which defines the intellectual capital as a synthesis of human and structural capital. Sveiby (1997) separates the intellectual capital to core competences of employees, internal and external structure and proposes that the intellectual capital based in the employees structural.

The majority of the proposals, focused on the separation of intellectual capital into three categories, most common as creativity, knowledge and other units (Granstrand, 1999), human structural and relations with third parties (Canibano, Sanchez, Chaminade, Olea, Escobar, \& Garcia-Ayuso, 1999), internal external structure and human capital (Brennan \& Connell, 2000), or core competences (Gunther, 2001), or into human structural and client capital (Mouritsen, Bukh, Larsen, \& Johansen, 2002).

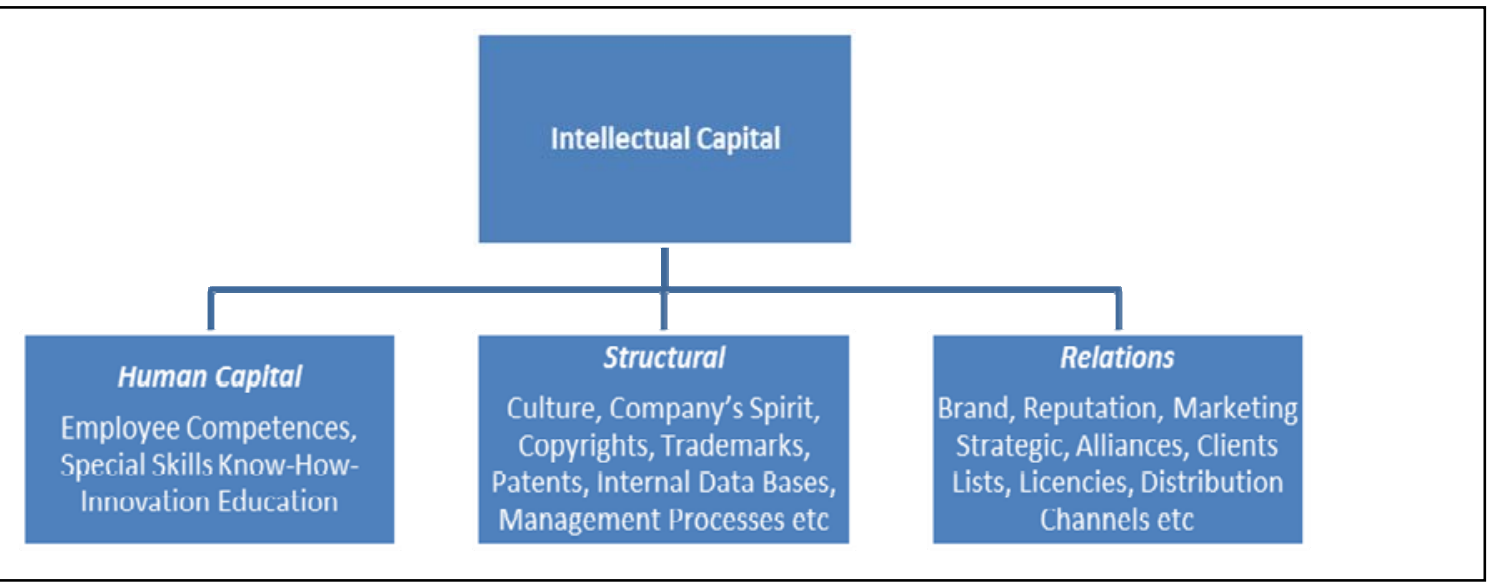

Figure 1. Proposals for categorization of intellectual capital (Seetharaman, Lock Teng Low, \& Saravanan, 2006).

The Financial Accounting Standard Board (FASB), proposes two different approaches, more detailed and with clear views for the categorization of different intangible assets of a company. Specifically, they propose the segregation in seven categories, using as a base the financing appearance of the economic situations. These proposals are described analytically, with concrete examples, thus helping in the explicit segregation of categories.

Thus FASB's proposal (2001) includes:

- Technology;

- Customers;

- Market;

- Workforce;

- Contracts;

- Organisational structure;

- Assets, recognized from the Law.

FASB's opinion helps particularly because it appears more explicit, creates fewer coverings between the categories, gives a more centralized and complete opinion of intangibles, and better helps the companies. 


\section{Partial Recognition of Some Intangible Assets}

Some characteristic examples of the most common intangible assets, which constitute the intellectual property of the company and can be sold separately or be transferred to others with a specific "life cycle", are listed above by Seetharaman et al. (2004).

Depending on the nature of every company, there are different assets: Assets without physical substance, without appearance in the financial statements, which the environment of the company (banks, suppliers, investors etc.) does not know of their existence. This gives a company the opportunity, the strategic key, the competitive advantage to become stronger between the competitors.

- Customers lists (deposits, loans, credit cards etc.);

- Libraries;

- Trademarks;

- Licences;

- Chemical formulas;

- Computer software;

- Electronic data bases;

- Contracts;

- Agreements of cooperation;

- Lists of clients;

- Contracts with clients;

- Customers relationships;

- Manuscripts;

- Product rights;

- Distribution channels;

- Drilling rights;

- Exclusive use of land property;

- Contracts with the employers;

- Environmental rights-air polluting;

- Recipes;

- Franchise;

- Joint ventures;

- Know how in production, organization, technology etc.;

- Contract management;

- Natural resources;

- Patents;

- Exclusive use of computer software;

- Schemes;

- Suppliers agreements - contracts;

- Well trained employees or team-workers.

All the above are only some of the intangibles that a company holds. There are more types of intangibles, depending on the firm, the company, and the product. There are not all kinds of intellectual capital of the above 
list in each company. For example, the main capital of a sports club, a football, or a basketball team that aims for the victory and the championship of the league is the players, the entire team, the captain, the coach, the training team, and the fans too. All these kinds of assets, without doubt, are assets for the club, but they aren't mentioned in the above list.

But trying to define the undefined, are we still trying to measure something that does not exist? How exactly is the immeasurable measured?

\section{Tools for Measurement-The Intangibles Worldwide}

Many tools for the evaluation of this type of company's property are developed. One of the most important inquiring programs, in the field of intangibles, which are reported and supported by a lot of later researchers themselves, constitutes the MERITUM Project (2002). The acronym of the name of this program is related to the measurement of the intangible, in order to be comprehended and improved by the administration of innovation (measuring intangibles to understand and improve innovation management). With the cooperation of six European countries (France, Finland, Denmark, Norway, Spain, and Sweden) the project began in November of 1998 and lasted for 30 months.

The objective of this particular program, which was financed by the European Committee, was to place limits for the measurement of this property, and to help and improve the decision makings for management. More analytically, the five objectives of this specific program were to create a form for categorisation of intangibles and a recorded system for management and control, European practices in the measurement of intangible assets and the determination of contribution of intellectual property in the operation of capital markets as a result of market's data analysis and enter limits in the measurement and the appearance of these intangibles in the financial statements of enterprise. The specific inquiring program categorizes the intangible assets to intellectual capital and other assets (Intangibles-Intangible Assets). It fixes, therefore, as intangible non-financing sources, like future economic utilities, without material substance, that are controlled by the enterprise as a result of previous synergies or transactions and can or cannot be the object of transaction individually from other corporate assets. The intellectual capital includes all the types of intangibles which belong to or are used by the enterprise, developed officially or informally. It is something more than total human, structural dynamic and the sources of the entire enterprise that the enterprise uses in order to create value. According to this program, the intangible assets portray the total of intangible elements of intellectual capital, which are recognized as assets, according to the accounting models.

The earliest example of a tool that solves the problem was the "Navigator" from the Swedish Security Company Skandia (Edvinsson, 1997). This tool was developed due to an intense wish for more information in the annual financial statements.

A different approach is presented by Sveiby (1997). The model that Sveiby developed, the "intangible assets matrix”, was used by the Swedish Company Celmi. This form provides information with regard to indicators of growth, renewal, efficiency, stability, and dangers that include the three categories of intangibles that are recognized in an enterprise: the competences of workers, the internal structure, and the exterior structure of enterprise. This method recognizes the intangible assets in non-monetary indicators with roots in the management of knowledge.

Another proposal is Stewart's (2007) “IC Navigator”; a map that detects, portrays, and measures the intangible assets of enterprise. In this method, each part (human capital, client relations, and structure of the company), is 
portrayed in a separate axis. The great advantage of this method is the possibility of comparison between the enterprises. Facing the problem of regular examination of occasions of investment, M'Pherson and Pike (2001) of Systems and Values Ltd., propose a very powerful opinion for the measurement of intangible resources, IVM (Intangible VALUE Measurement). A similar tool is table IC-Index that was developed by the London-based Intellectual Capital Services (ICS), which uses a line of indicators and calculates a total value of enterprise, something particularly useful for occasions of investment and very important for analysis of cost of/profit.

In order to stimulate the administration of enterprise another tool was developed, the EVA (Economic VALUE Added). The problem that this tool was called to solve was the false decisions that are taken due to false calculations of traditional indicators instead of cash flow, focusing on the interest of the management in the creation of intangible value.

The proposal of Kaplan and Norton (2001) is a tool which clarifies and applies the strategies of enterprise. With its main purpose the creation of operational strategies, Kaplan and Norton's table of Balanced Scorecard allows the measurement and management of strategically important assets of enterprise. With the five prospects (financing, customers, internal activities, knowledge, and growth), the table of balanced scorecard was not drawn exclusively for the management of intangibles, but for the measurement of strategic output of enterprise in total. The table of Kaplan and Norton not only measures the output but also is an important mechanism of feedback for the attribution of activities of Management. An interesting field for development of Kaplan and Norton's approach is a model which allows the internal control of intangibles while simultaneously offering information for the exterior shareholders. The problem that emerged was in which way the long-term strategy of enterprise would be connected with its short-term actions.

The above proposed methods are only some of the international proposals in the intangible field. It depends on what we want, what and why we try to define and measure. The appropriate tool or method from the entire literature depends on what the aim of the research (evaluation, measurement etc.) is or on the users of the research product (management, suppliers, investors etc.).

Table 1

Different Methods Depending From the Problem

\begin{tabular}{lllll}
\hline Why/how & Financial methods & Measurement of value & Estimate of value & Measure \\
\hline $\begin{array}{l}\text { Improve the internal } \\
\text { management }\end{array}$ & $\begin{array}{l}\text { Technology factors } \\
\text { (Khoury, 1994) }\end{array}$ & $\begin{array}{l}\text { Holistic value approach } \\
\text { (Pike \& Roos, 2000) }\end{array}$ & $\begin{array}{l}\text { Intellectual capital } \\
\text { benchmarking system } \\
\text { (María Viedma Marti, } \\
\text { 2001) }\end{array}$ & $\begin{array}{l}\text { IC audit } \\
\text { (Brooking, 1996) }\end{array}$ \\
\hline $\begin{array}{l}\text { Improvement of exterior } \\
\text { information }\end{array}$ & $\begin{array}{llll}\text { Intangible capital (Gu \& } \\
\text { Lev, 2002) }\end{array}$ & $\begin{array}{l}\text { Value chain scoreboard } \\
\text { (Lev, 2001) }\end{array}$ & $\begin{array}{l}\text { Skandia navigator } \\
\text { (Edvinsson \& Malone, } \\
\text { Motives that arise from }\end{array}$ \\
$\begin{array}{llll}\text { legislation or } \\
\text { transactions }\end{array}$ & $\begin{array}{l}\text { Cost, market \& income } \\
\text { approach (Reily \& }\end{array}$ & & & Schweihs, 1999) \\
\hline
\end{tabular}

\section{Advertisement as an Intangible Asset}

\section{The Brand Advertising Campaign as an Intangible Asset}

According to Fotidou, Gkinoglou, and Pestriva (2008), the fixed assets of an enterprise consist of a long-term tangible piece of property, with natural substance that a firm owns and uses in the production of its 
income and is not expected to be consumed or converted into cash any sooner than at least one year's time.

An intangible asset is an asset that is not physical in nature, such as patents, trademarks, copyrights, goodwill, and brand recognition. The firm acquires them with the intention of keeping them for a period longer than a year. An intangible asset can be characterized as either an indefinite or a definite asset depending on its specifics. A company brand name is considered to be an indefinite asset, as it stays within the company as long as the company continues operations. However, if a company enters a legal agreement to operate under another company's patent, with no plans of extending the agreement, it would have a limited life and would be classified as a definite asset. An advertisement is the activity that contributes in the reinforcement of demand, in the increase of market share, and in the increase of profits in the long run.

Enterprise implements an advertising program in order to achieve various objectives. These objectives define the different types of advertisement, which are:

- Primary demand advertising;

- Selective demand advertising;

- Brand loyalty advertising;

- Sales promotion advertising;

- Display advertising;

- Business to business advertising;

- Retail advertising;

- General advertisement of enterprise, organism, institution;

- Cooperative advertising;

- Political advertisement, aiming at the consolidation of brand name of the enterprise.

The objective of establishing a firm's brand name is realised with the specific advertising campaigns:

(1) Primary demand advertising;

(2) Selective demand advertising;

(3) Brand loyalty advertising;

(4) General advertisement of enterprise, organism, institution.

\section{Contribution of Advertising Program to the Aim of the Enterprise}

From the above definitions, it can be elicited that an advertising program that aims at the establishment of firm's brand name, also contributes to the realisation of profit, which is the primary target of an enterprise. On the other hand, the fixed assets also contribute to the realisation of a firm's primary target.

Therefore, it can be suggested that an advertising program, which aims at the establishment of a firm's brand name, can be viewed as a fixed asset. Moreover, as advertisement has no material essence, it can be considered as an intangible asset.

Consequently, based on the above syllogism, it can be assumed that this kind of advertising expenses should be recorded as an intangible asset and be depreciated as all assets.

By behavioural researches, a three-year period is considered as an expected duration of an advertising program's impact on consumers' conscience. Thus, this expense should be depreciated either at a constant rate or at a decreasing rate. According to a research in enterprises of foods sector, the expenses of an advertising program contribute to the profitability of the enterprise for more than one year. Furthermore, the creation of a brand name and the guarantee of customer devotion yield profits in a long-term perspective. 


\section{PACE as a Measuring Tool}

\section{PACE From Altec Research Program Division}

In 2006, Altec Research Development (Altec Research Program Division, 2006), developed a new methodology, based on the Weightless Wealth Toolkit by Andriessen (2004), a tool to measure the intangible assets that contribute to project management. Based on the experience established from the team's involvement in several projects, there is clear evidence that a considerable majority of projects fail because they do not succeed in identifying their individual purpose in terms of knowledge produced and excellence achieved.

The aim of this tool of measurement is simply a quantitative recording in monetary units, of all the intangibles that came out as a project's product. These intangibles will be useful either for the entire team-project or for all the individual parties of a research division

\section{The Suggested Approach}

The approach we follow in PACE is built on a seven-step operation:

(1) Step 1: SWOT analysis

(2) Step 2: Identification of each partner's core competences

(3) Step 3: Stress tests and valuation of core competences:

Added value test;

Competitiveness test;

Potentiality test;

Sustainability test;

Robustness test;

Valuation of core competences.

(4) Step 4: Project assets

(5) Step 5: Exploitation strategies

(6) Step 6: Roadmaps

(7) Step 7: Strategy quantification

Step 1: SWOT analysis. The approach is based on the recognition and examination of Strengths, Weaknesses, Opportunities, and Threats (SWOT), a rather all-time classic technique that aims at helping during the early stages of pre-processing input in order to achieve the formation and classification of the set of particular project developments and results in which the project will be delivered. SWOT will be performed for the project as a whole. This includes the project approach, methodology, and partners’ assets. In this respect, it can be treated as a "rough guide" to help people like corporate decision-makers and research directors to improve their processes and increase the value they shall be getting from the project, while it can also possibly help them to focus better on their research work items. Strengths category includes an internal list (internal: to the consortium and each partner separately, and regarding the project itself) of all the "strong" points of the subject under study (can be either the overall integrated project outcome or the particular developments which will be led by the partner under consideration), while the weaknesses category includes an internal list of all the possible "weak" points.

Respectively the opportunities category holds an external list (external: to the consortium and each partner separately, and regarding the project itself) of the opportunities that might exist regarding the exploitation of the project outcomes, while the threats category includes the external threats that might be faced while trying to exploit the project outcomes. 


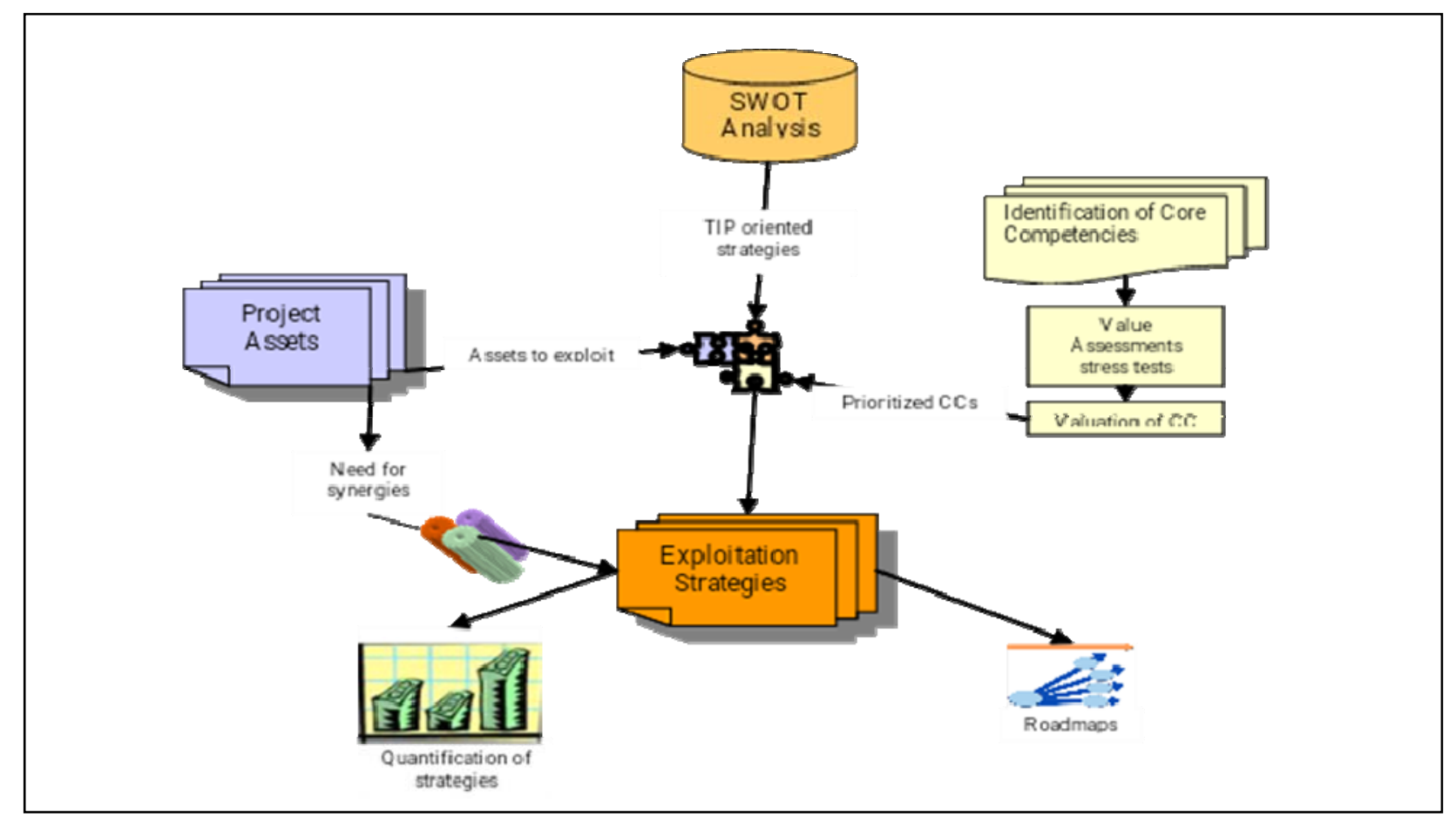

Figure 2. Altec (2006) PACE exploitation toolkit.

Step 2: Identification of core competencies. The second step refers to the identification of each partner's core competencies (CC) with respect to the project-both those that are contributed by each partner to the project and which shall affect its final outcomes, and those that are affected by the project. For each core competence the partner has to define which intangible assets are related and what is the current contribution margin in a monetary fashion. A special point should be made for non-commercial partners. These partners should identify the core competencies contributing to the participating project. The contribution margin of these CCs should be identified as such, i.e. if partner X participates in a project, this has been based on one or more CCs that contribute to this project. The partner's income is based on his work and expertise, which in turn can be related to the core competencies owned by the partner, and offered to the project. Thus, a monetary estimation of the CCs contribution margin can be made.

In the end of this step the partner should get a complete list of the core competencies of his organisation, a clear view of his legacy intangible assets and an indication (through the contribution margins) of the most valuable core competencies.

Step 3: Evaluation of core competencies. At this stage, according to the methodology, each partner tries to evaluate the core competencies offered to and/or affected by the project. Valuation is carried out with respect to the contribution of each particular core competence to the current and foreseen business of each partner. The valuation is based upon five stress tests, in terms of checklists that should be completed for each identified core competence. These checklists are shown below. For each question the partner should place a binary (yes = 1/no $=0$ ) indicator. The sum of these indicators will comprise the total score of the stress test and will be taken into account in the actual valuation. The total effort of valuation (based on Prof. Andriessen's method) is based on the questionnaire (yes-no), where every core competence that contributed to the project, evaluates for the value added to the Project, the Competitiveness, the Potential, the Sustainability, and the Robustness. 
The results are presented in a total matrix (Table 6), based on steps 1-7, and in the contribution margin of each core competence in a five-year life cycle, as a result we have a monetary evaluation for each core competence.

\section{Example of Choosing Between Two Different Strategies With PACE}

As an example in Tables 2-6, the entire methodology can be seen. Continuing this method, we can assume that if we have two different strategies to choose from, taking into consideration the present value of each strategy (the cost of following the specific strategy), also taking into account the result from the PACE for each strategy, we have the future value of money that is invested today.

Table 2

Added Value Checklist

\begin{tabular}{|l|c|}
\hline \multicolumn{1}{|c|}{ Added value checklist } & $\begin{array}{c}\text { Score (1= yes, } \\
0=\text { no) }\end{array}$ \\
\hline \multicolumn{1}{|c|}{ Added value } & \\
\hline $\begin{array}{l}\text { The core competence offers a subst ant ial benefit for your customers or a substantial cost } \\
\text { saving for your company. }\end{array}$ & \\
\hline $\begin{array}{l}\text { Customers demand this specific benefit or cost saving } \\
\text { This benefit is important for a large number of cust omers; it goes futher than just 'nice to } \\
\text { have'. }\end{array}$ & \\
\hline $\begin{array}{l}\text { Cust omers will cont inue expect ing this senefit in the near future; it is not smply a passing } \\
\text { fancy. }\end{array}$ & \\
\hline $\begin{array}{l}\text { Leadership in this core competence makes customers think you are different from the } \\
\text { compet ition, rather than just better. }\end{array}$ & \\
\hline Total score added value & 0 \\
\hline
\end{tabular}

Table 3

Competitiveness Checklist

\begin{tabular}{|l|c|}
\hline \multicolumn{1}{|c|}{ Competitiveness checklist } & $\begin{array}{c}\text { Score (1=yes, } \\
0=\text { no) }\end{array}$ \\
\hline \multicolumn{1}{|c|}{ Compet it iveness } & \\
\hline Fewer than five of your competitors share this particular competence. & \\
\hline You are superior to your competitors in most aspects of this particular competence. & \\
\hline You invest substantially more time and money in this competence than your competitors. & \\
\hline Your customers choose your products or services largely because you have this competence. & \\
\hline $\begin{array}{l}\text { Your leadership in this competence is generally recognized and can be illustrated by articles in } \\
\text { trade journals, patents, and so on. }\end{array}$ & 0 \\
\hline Total score competitiveness & \\
\hline
\end{tabular}

Table 4

Potential Checklist

\begin{tabular}{|l|c|}
\hline \multicolumn{1}{|c|}{ Potential checklist } & $\begin{array}{c}\text { Score (1=yes, } \\
\text { Pono) }\end{array}$ \\
\hline \multicolumn{1}{|c|}{ Pot ential } & \\
\hline $\begin{array}{l}\text { There is an increasing demand for products / services that can be provided thanks to this } \\
\text { core competence. }\end{array}$ & \\
\hline The core competence allows the development of new products and services in the fut ure. & \\
\hline The core competence allows new markets to be entered in the fut ure. & \\
\hline $\begin{array}{l}\text { There are no economic threats (customers, suppliers, competitors) that will adversey affect } \\
\text { the use of this competence. }\end{array}$ & \\
\hline $\begin{array}{l}\text { There are no social threats (regulatory and social) that will adversely affect the use of this } \\
\text { competence. }\end{array}$ & 0 \\
\hline Total score potential & \\
\hline
\end{tabular}


Table 5

Sustainability Checklist

\begin{tabular}{|l|c|}
\hline \multicolumn{1}{|c|}{ Sustainability checklist } & $\begin{array}{c}\text { Score (1= yes, } \\
0=\text { no) }\end{array}$ \\
\hline \multicolumn{1}{|c|}{ Suinabilit y } & \\
\hline This core competence is scarce in your branch. & \\
\hline $\begin{array}{l}\text { It would require considerable investment s in time and / or money for competitors to master } \\
\text { this competence. }\end{array}$ & \\
\hline Patents, trademarks, and other legal measures protect components of the competence. & \\
\hline $\begin{array}{l}\text { This competence is a combination of a number of int angibles such as skills, knowledge, } \\
\text { processes, and corporate culture, thus making it difficult to copy. }\end{array}$ & 0 \\
\hline This competence cannot be obtained through acquisition or from other outside sources. & 0 \\
\hline Total score sustainability & \\
\hline
\end{tabular}

Table 6

Robustness Checklist

\begin{tabular}{|l|c|}
\hline \multicolumn{1}{|c|}{ Robustness checklist } & \multicolumn{1}{|c|}{$\begin{array}{c}\text { Score (1=yes, } \\
0=\text { no) }\end{array}$} \\
\hline $\begin{array}{l}\text { The group of people that possesses the skills and knowledge crucial for this competence is } \\
\text { vulnerable. }\end{array}$ & \\
\hline The values and norms on which this competence is built are under pressure. & \\
\hline $\begin{array}{l}\text { The technology and information technology systems that form part of this competence are } \\
\text { vulnerable. }\end{array}$ & \\
\hline The primary and management processes that this competence uses are unreliable. & \\
\hline $\begin{array}{l}\text { The endowments on which this core competence depends (like the corporate image or the } \\
\text { installed client base) are vulnerable. }\end{array}$ & \\
\hline Total = A & \\
\hline Total score robustness $=5-\mathrm{A}$ & 5 \\
\hline
\end{tabular}

Table 7

Results of the PACE Exploitation Toolkit

\begin{tabular}{|c|c|c|c|c|c|c|c|c|c|c|}
\hline Competence & $C M$ & $G$ & $S$ & $t=1$ & $t=2$ & $t=3$ & $t=4$ & $t=5$ & $R$ & Value \\
\hline $\begin{array}{l}\text { EXTENSIVE DOMAIN KNOW- } \\
\text { HOW }\end{array}$ & $120.000,00$ & $\mathbf{0}$ & 0 & $120.000,00$ & $120.000,00$ & $120.000,00$ & $120.000,00$ & $120.000,00$ & $100 \%$ & $600.000,00$ \\
\hline EXPERTISE IN ERP SYSTEMS & $1.100 .000,00$ & $\mathbf{0}$ & 0 & $1.100 .000,00$ & $1.100 .000,00$ & $1.100 .000,00$ & $1.100 .000,00$ & $1.100 .000,00$ & $100 \%$ & $5.500 .000,00$ \\
\hline & 0,00 & $\mathbf{0}$ & 0 & 0,00 & \begin{tabular}{|l|}
0,00 \\
\end{tabular} & \begin{tabular}{|l|}
0,00 \\
\end{tabular} & \begin{tabular}{|l|}
0,00 \\
\end{tabular} & 0,00 & $100 \%$ & 0,00 \\
\hline & 0,00 & $\mathbf{0}$ & 0 & 0,00 & 0,00 & 0,00 & 0,00 & 0,00 & $100 \%$ & 0,00 \\
\hline Total: & 0,00 & - & - & $1.220 .000,00$ & $1.220 .000,00$ & $1.220 .000,00$ & $120.000,00$ & $1.220 .000,00$ & - & $6.100 .000,00$ \\
\hline \multicolumn{11}{|c|}{$\begin{array}{l}\text { CM: Con:rlcution Margin in Edros } \\
\text { G: Grow:h }(\%)=\text { Added Vaue - Competitiveness + Potentiel } \\
\text { S: Sust ainability } \\
\text { t } 1,12, \ldots \text { retums for year } 1, \text { year } 2, \ldots \\
\text { R: Robusness }(\%) \text {. } \\
\text { Value: in Euros }\end{array}$} \\
\hline
\end{tabular}

This is the most important step. Each project partner needs three sets of information for conducting his exploitation strategies. The first is the complete SWOT matrix as this was defined in the first step, the second is the list of his core competencies with their total values, and the third is the list of the defined project assets.

The strategies will be oriented as the Technology Implementation Plan orders. This means that the framework should offer strategic alternatives that should/must fall into the following categories. In order to accomplish this task each partner should look at his core competencies and prioritize them according to their contribution margin. Following this, for each one of the project's assets, the partners should look at the SWOT table to try to identify elementary strategies (through the SWOT combinations: SO, WO, WT, ST) by 
exploiting the asset under examination. Mentioned earlier, these strategies should fall under one of the following (TIP) categories:

(1) IMP: improvement or change of internal processes;

(2) NPS: new product/ service development;

(3) LIC: revenues through license agreement;

(4) MKT: revenues through marketing agreement;

(5) MAN: revenues through manufacturing agreement;

(6) JV: revenues through establishment of a joint enterprise or partnership;

(7) PPP: revenues through establishment of a private-public partnership;

(8) FIN: revenues through development financing;

(9) VC: revenues through venture capital/spin-off fundraising;

(10) CONS: revenues through provision of consultancy;

(11) R\&D: revenues through further research or development.

\section{Conclusion “Unmeasurable or Measurable?”}

Finally, the subject of intangible assets is a daily pastime for the enterprises. Measurement and management of the intangible property are not so easy and do not take place in the same way with the materials. By empirical research, as Gu and Lev (2001) mention, it is realised that traditional industries, such as aeronautics, defence, or oil, have a large and intense presence of intangible assets. It could constitute an element of future research in the comparison of intangible assets, between the traditional heavy industries and the new industries as the industry of multimedia. As Zambon (2006) observes, the under-investigation of the scientific region known as intangible assets or Intellectual Capital, he still does not give an explicit and strict term while likely he can never delimit what the intangible assets are. Even if this field of research seems to be deprived as an internationally acceptable language of communication, the research is found in a good level of determination of objective of (intangible assets) but also other assets that are related with them. A lot of articles and opinions have been written and a wide interest has been expressed by all involved in the enterprise's parts (managerial executives, accountants, academicians, advisers etc.) for the comprehension of these enterprise's assets.

The paradox that has to face the economic practice, despite the uncertain scientific delimitation of particular subject, is that as long as the economic system and the enterprise based more and more on their intangibles and their intellectual capital, the more powerful they become, while these resources are the keystones for the growth and the creation of value. Of course, as long as more intense investment in intangible resources makes not only the enterprises but also the general economic system, so much more vulnerable.

As a result, few examples of empirical study exist. Moreover, in the international literature, there is observed a lack of a theoretical frame which could be argued in the practice. Is absent, that is to say, a concrete definition of intangible and mental-intellectual capital while also segregated in three categories, is not satisfactory. Most of the models that have been developed internationally for the measurement and assessment of intangible assets and intellectual capital are more qualitative than quantitative and this does not render these models particularly useful for the enterprises. The objectives of international bibliography are often very narrow and they cannot help the enterprise in the management of these resources. They are usually focused on the benefit of information with regard to the acquisition of intangibles, without however managing to describe in which way such information could be useful for the enterprise. 
The lack of a practical approach is obvious in the subject of intellectual capital, which could provide information and help to the enterprises. Future research will have various subjects such as: particularisation of objectives of research in the intangible with parallel proposals for management of these assets, proposals for exploitation in the practice of information that result from the study of intangibles to remain only in their localisation, examination of application in the practice of theories that have been developed, focalisation in concrete subjects of intangibles except the knowledge, growth of theoretical background, applicable in the practice in regard to the management of this fortune of enterprises, generalisation of models of measurement, which might express, portray, and include all the types of intangible assets that likely possesses the enterprise or growth of a new model. Also, it would be important that the effort for concretisation is in the practice of empirical research, in order to investigate how much is functional in the management of intangible assets.

Deductively, we can realise how distinct their contribution is in the creation of competitive advantage and consequently, the maintenance of enterprise in high level of competition.

The next challenge for all the involved parts (enterprises—state — shareholders-investors—workers—ad -ministration-economic advisers-accountants-academicians etc.) is the recognition and the establishment of a way of management, quantity survey and depiction in the continuously more intangible-based economic environment.

The entire "intangible community" seems to be very closed, more than ever, to measure the un-exploitable and mysterious, unmeasurable, non-tangible fortune of enterprise that is that of Intangible Assets.

\section{References}

Altec SA. (2006). Research Programs division "pace exploitation toolkit”. For more analysis can visit http://www.altec.gr Andriessen, D. (2004). Making sense of intellectual capital: Designing a method for the valuation of intangibles. Routledge.

Brennan, N., \& Connell, B. (2000). Intellectual capital: Current issues and policy implications. Journal of Intellectual Capital, 1(3), 206-240

Brooking, A. (1996). Intelectual capital. London: Core Asset for the Third Millenium Enterprise, International Thomson Business Press.

Canibano, L., Sanchez, P., Chaminade, C., Olea, M., Escobar, C. G., \& Garcia-Ayuso, M. (1999). Measuring intangibles to understand and improve innovation management. Preliminary Results. Universidad Autónoma de Madrid.

Edvinsson, L., \& Malone, M. S. (1997). Intellectual capital: Realizing your company’s true value by finding its hidden brainpower.

Edvinsson, L. (1997). Developing intellectual capital at Skandia. Long Range Planning, 30(3), 320-373.

Granstrand, O. (1999). The economics and management of intellectual property. Cheltenham: Edward Elgar Publishing.

Gu, F., \& Lev, B. (2001). Intangible assets: Measurement, drivers, usefulness. New York.

Gunther, T. (2001). Controlling intangible assets under the framework of value-based management. Kostenrechnungspraxis No Sonderheft, 1, 53-62.

FASB, N. (2001). Getting a grip on intangible assets-what they are, why they matter, and who should be managing them in your organization. Harvard Management Update, 6(2), 6-8.

Fotidou, A., Gkinoglou, M., Pestriva, K. (2007). Advertisement program: An expense or an intangible asset for the company. Proceedings of the 5th International Conference on New Horizons in Industry, Business and Education (NHIBE 2007).

Kaplan, R. S., \& Norton, D. P. (2001). The strategy-focused organization: How balanced scorecard companies thrive in the new business environment. Harvard Business Press.

Khoury, S. (1994). Valuing intellectual properties. Dow Chemical Company.

Lev, B. (2001). Intangibles: Management, measurement and reporting. Washington, DC: Bookings Institution Press.

M'Pherson, P. K., \& Pike, S. (2001). Accounting, empirical measurement and intellectual capital. Journal of Intellectual Capital, 2(3), 246-260. 
María Viedma Marti, J. (2001). ICBS—Intellectual capital benchmarking system. Journal of Intellectual Capital, 2(2), 148-165. Meritum, P. (2002). Guidelines for managing and reporting on intangibles. Fundación Airtel-Vodafone.

Mouritsen, J., Bukh, P. N., Larsen, H. T., \& Johansen, M. R. (2002). Developing and managing knowledge through intellectual capital statements. Journal of Intellectual Capital, 3(1), 10-29.

Pike, S., \& Roos, G. (2000). Intellectual capital measurement and holistic value approach (HVA). Works Institute Journal (Japan), 42(October/November).

Reilly, R. F., \& Schweihs, R. P. (1998). Valuing intangible assets. McGraw Hill Professional.

Seetharaman, A., Lock Teng Low, K., \& Saravanan, A. S. (2004). Comparative justification on intellectual capital. Journal of Intellectual Capital, 5(4), 522-539.

Stewart, T. A. (2007). The wealth of knowledge: Intellectual capital and the twenty-first century organization. Crown Business.

Sveiby, K. E. (1997). The new organizational wealth: Managing \& measuring knowledge-based assets. Berrett-Koehler Publishers.

Zambon, S. (2006). Is there a disciplinary field called “intangibles and intellectual capital”? Journal of Intellectual Capital, 7(4). 